Poznatky o současném stavu výuky společenských věd na gymnáziích svědči o tom, že těžiště výuky tradičně spočivá ve filozofii. Takovému pojetí nahrává i připrava učitelů občanské nauky na pedagogických fakultách, kde pozornost věnovaná co do rozsahu filozofii je nesrovnatelná s ostatnimi vědami a už tím se u posluchačủ vytvář́ model jejich budoucí pedagogické práce. Obdobný je i na gymnáziích, kde také převažuji dějiny filozofie, které disponují poměrně širokým rozsahem odborné literatury, od autentických textå až po populární učebnice. Dějiny je navíc možno interpretovat bez obav $z$ prrípadné kritiky a bez nároku na samostatný, tvůrči přistup. Nakonec znalost antických filozofü patři ke klasickému vzdělání už po staletí a takto pojatý učební plán lze vždycky obhájit. Dějiny filozofie tvoři také podstatnou část maturitních otázek a podobně strukturovaná je i učebnice, kterou hojně používají jak pedagogové, tak studenti připravující se na maturitu. Ostatním společenským vědám je věnována pozornost okrajově, výuka se omezuje na základni pojmy a představitele i přesto, že učební osonovy předpokládají komplexnějši výklad.

Takový způsob výuky společenských věd je podle názoru řešitelủ př́liš konzervativní, protože:

a) preference dějin filozofie vnáši do výuky tradiční schéma, které je možná pohodlné, ale neodpovídá bezprostředně na aktuální otázky a snižuje atraktivitu předmětu;

b) nadvláda filozofie je do určité míry nadhodnocením významu vědeckého světového názoru (viz marxismus - leninismus), tj. reliktem minulosti;

c) filozofie je $v$ této souvislosti, zejména na úrovni středních škol, chápána mechanicky, jako přehled názori̊, které vysvětlujî svět, ale bez př́mé vazby na reálné chování

d) orientace na dějiny implantuje výuce statický ráz, umožn̆uje mechanický, netvưrčí přistup a obdob- né přijímání předmětu studenty, na kterých nemusí zanechat hlubší stopu.

V době, kdy se mírou vzdělanosti pomalu stává způsobilost pracovat s internetem, by se mělo změnit těžiště výuky základů společenských věd. Studenti střednich škol představuji věkovou kategorii, která si klade globální otázky lidstva a ty nejsou vždy totožné s těmi, které si kladli jejich rodiče, a zároveň hledá stejně jako předchozí generace svoji vlastní identitu. Intenzivně se socializuje v nových, zejména vrstevnických skupinách, snaží se zbavit závislosti na autoritách a kriticky hodnotí život ve společnosti. Mladí lidé nabývají zkušeností z oblastí, které jsou předmětem sociologických teorií, takže sociologie múže při výuce:

a) lépe než kupř. filozofie využívat znalostí a osobních zkušenosti studentı̊;

b) věcně vnímat reálné sociální situace, rozumět jim a nalézat vhodné formy chování;

c) být zajímavá pro širši okruh studentů, než jsou ti humanitně orientovani, protože bezprostředněji odpovídá na otázky, které jsou pro ně aktuální;

d) plnit funkci východiska pro vysvětlení sociálních jevů, které svou povahou vyžadují multidisciplinární, komplexní přistup. Tím není snižován význam hlubšího, filozofického chápání světa, ale současná standardní výuka společenských věd ho mnohdy neposkytuje. A zařazení tzv. aktuálních témat do učebního programu ještě neznamená modernizaci.

Cílem společenských věd na středních školách by se měla stát výchova $\mathrm{k}$ občanství v demokratické společnosti. To by ovšem vyžadovalo převrat současného tradičního modelu výuky, včetně přípravy pedagogů a tomu zatím nic nenasvědčuje.

Jitka Havlová

\title{
Piotr Sztompka o světové a polské sociologii
}

Časopis hlavního výboru Polské sociologické společnosti Informacja Bieźąca č. $56 \mathrm{z}$ prosince 1998 uveřejnil rozhovor s P. Sztompkou, který byl jako jediný reprezentant sociologie střední a východní Evropy zvolen na XIV. světovém sociologickém kongresu, konaném v létě 1998 v Montrealu, do vedení Mezinárodní sociologické asociace (ISA), a to ve funkci viceprezidenta. P. Sztompka je profesorem Jagellonské univerzity v Krakově, odborně orientova- ným zejména na problematiku obecné sociologické teorie. K jeho nejvýznamnějšim knižním publikacím patř̌i Metoda funkcjonalna w socjologii i antropologii społecznej (Wroctaw 1971), System and Function. Toward a Theory of Society (New York 1974), R. Merton. An Intellectual Profile (New York 1986), Society in Action: The Theory of Social Becoming (Cambridge 1991) a The Sociology of Social Change (Oxford 1993). 
Protože $v$ uvedeném rozhovoru vyslovil $P$. Sztompka řadu myšlenek, jež by mohly zajimat i naši sociologickou veřejnost, dovoluji si o nich informovat.

Ve své první odpovědi seznámil polský sociolog čtenáře se zákulisím voleb vedení ISA. Tyto volby jsou dvoustupňové. $V$ roce předcházejícím světovému kongresu pracuje několikačlenná volební komise, jež vybírá pro každou funkci dva až tři kandidáty. Jejich vědecké životopisy se rozesílají půl roku před kongresem všem členům organizace. Volba sama probíhá na kongresu, kde více než stočlenné grémium složené $\mathrm{z}$ představitelů jednotlivých zemí, $\mathrm{z}$ nichž každá má jeden hlas bez ohledu na velikost, a ze zástupcủ výzkumných výborů ISA, disponujicích rovněž jedním hlasem, tajně hlasuje. P. Sztompka kandidující na výše zmíněnou funkci měl před tímto grémiem $\mathrm{k}$ dispozici pět minut na své programové vystoupení. „Riskoval jsem“, řiká polský sociolog, ,a jednoznačně jsem připomněl, že ISA je vědeckou společností, a nikoli odborovým svazem nebo jakousi malou OSN, a proto jediným kritériem voleb musí být nejvyšši kvalita vědeckých výsledků a nic více. Vyslovil jsem kacírskou myšlenku, že věda je svou povahou elitární a hierarchická, a jako své volební heslo jsem uvedl Excellence rather then balance, což znamená klást dủraz na meritum, nikoli na rovnováhu kontinentủ, jazykových oblastí, ras, pohlaví nebo dokonce sexuálnílch orientaci. Byla to tak zjevná výzva tzv. politické správnosti, až se někteři kolegové domnívali, že jsem spáchal volební sebevraždu. Dopadlo to však úplně jinak. Zvitězil jsem velkou většinou hlasů. Naopak kandidát na prezidenta ISA Švéd Goran Therborn prohrál s Albertem Martinellim z Milána snad právě proto, že vsadil na tzv. rovnováhu a svůj projev pronesl ve čtyřech jazycích, každou větu v jiném." Podle Sztompky se zdá, že do světové sociologické komunity se vrací zdravý rozum a excesy ultraliberálního egalitarismu máme naštěstí za sebou.

Další otázka rozhovoru byla zaměřena na to, proč mezi zvolenými vedoucími funkcionáři ISA chybí reprezentanti zemí Latinské Ameriky. Podle Sztompky je to tím, že tento kontinent nepředstavuje v sociologii velkou sílu. Na mnohem vyšši úrovni jsou tam např. politické vědy. I v Brazílii se tamější nejvýznamnější sociolog Fernando Cardoso začal zabývat politikou a stal se prezidentem země. V Argentině, kterou Sztompka nedávno navštívil, činí sociologie teprve první krůčky. „Autokratické systémy“, vysvětluje polský sociolog, ,sociologii přiliš nemilovaly. $Z$ toho dủvodu zde chybí pozoru- hodné výsledky i slavná jména. Když tedy voliči na kongresu začali výrazně přihlížet $\mathrm{k}$ meritorním kritériím, kandidáti z Latinské Ameriky neměli šanci. Mủj skrovný podíl na jejich porážce spočíval v tom, že mým protikandidátem byl prezident Venezuelské sociologické společnosti Roberto Briceno-Leon. Věrim však, že se to pozvolna bude měnit, nebot Latinská Amerika je světadíl s ohromným lidským potenciálem i s nádhernou kulturou."

Třetí otázka se týkala ,geografického pulzu“ světového sociologického života, tedy toho, zda lze dnes hovořit o teoretické a tematické specifičnosti sociologie pěstované $\mathrm{v}$ různých oblastech světa. Podle Sztompky je světová sociologie ilustrací procesu, který sama s takovým zaujetím zkoumâ, tj. globalizace. Právẽ jemu bylo i na kongresu mezi 3900 přednesenými referáty věnováno nejvíce pozornosti. Rubem globalizace je, jak známo, hájení vlastní odlišnosti. Druhým nejfrekventovanějším tématem kongresových referátů byla tudiž identita. „Čím více se světová sociologie stává $\mathrm{z}$ hlediska výzkumných standardů, metod, technik, pojmového kánonu, tematických oblasti apod. jednotnou, “ řiká P. Sztompka, ,tím silněji se obrací k lokálním, národním či regionálním teoretickým tradicím. Zdá se mi, že právě v teorii se obnovuje podstatná diferenciace a že se zde po téměr celém století nadvlády americké sociologie vracime do zlatého věku evropské sociologie, tj. k sociologické klasice. Na kongresu jsem spolu s anglickými, francouzskými, německými, švédskými a španělskými kolegy představil první čislo nového čtvrtletníku European Journal of Social Theory. Již několik let existuje Evropská sociologická společnost (ESA). To vše jsou znamení doby."

Dalši dvě otázky si všimaly polské sociologie, zejména toho, jak se jeví z hlediska světové sociologie a jaké je její místo mezi sociologiemi dalších zemí střední a východní Evropy. To, že byl do vedení ISA zvolen právě polský sociolog, nepovažuje Sztompka za náhodu. Polsko žije v paměti světové sociologické obce stále jako země, kde od poloviny 50. let existovala normální, vědecká sociologie, jež byla ve světě viditelná a přispivala významným vkladem do světové sociologie, a to i v ideologicky nejcitlivějších oblastech teorie. Nezapomíná se, že jedním ze zakladatelủ a viceprezidentem ISA byl Stanisław Ossowski a jejím prezidentem v letech 1966-70 Jan Szczepański. Nezapomíná se ani na to, jakou roli ve výkonném výboru ISA sehráli Stefan Nowak a Magdalena Sokołowská. To jsou podle Sztompkových slov ,velmi dobré tradice, na které můžeme být hrdi. Nelze však usnout na vavř́nech. Dnes jsme už mnohem méně výjimeční. Sociologie 
se obrodila a velmi dynamicky se rozviji ve všech sousedních zemích. A u nás tep sociologie jako by trochu zeslábl. Edituji sérii překladů nejlepších knih zahraničních autorủ věnovaných východní Evropě, nazvanou Měnící se Evropa 89. Doposud vyšly práce Therbornovy, Judtovy a Brubakerovy, zanedlouho se objeví díla Offeho a Delanyho. Popravdě řečeno, nemám nedostatek, ale spíše nadbytek potenciálních titulů. Je možné, že je ještě př́lišs brzo na syntézy z pera nás samotných, účastníkủ transformace. Možná že se vnějším pozorovatelủm o nás píše snadněji. Jestliže však výzvu nepřijmeme, naše výjimečnost ve světě nesporně skončí".

Vzniká otázka, zda nyní, kdy se Polsko stalo zemí relativně normální a zájem médií i západních sociologů se přesouvá na Rusko i jiné oblasti světa, není z hlediska vývoje obecné teorie i z hlediska odvětvových teorií, jež se vztahuji např. na sociální procesy, tato ztráta pozornosti věnované polské společnosti předčasná.

Sztompka na to odpovídá, že velká sociologická díla jsou dětmi velkých společenských přelomủ. Tak tomu bylo v 19. století, kdy se celá sociologická klasika rodila ze zaujetí novým, vznikajícím sociálním řádem. „S přelomem, který přinesl rok 1989, nám, polským sociologům, i sociologům sousedních zemí dějiny nadělily nebývalý dárek: fascinující laboratoř sociálních změn. Domnivám se, že od finále systémové transformace jsme ještě velmi vzdáleni. Je možné, že se bližime $\mathrm{k}$ určité stabilizaci ekonomického systému či právních institucí, upevňují se demokratické formy, ale v oblasti kultury, mentality, životních vzorů, hodnot, zvyků, způsobủ, reakcí srdce (použiji-li Tocquevillovy metafory) máme $\mathrm{k}$ normalitě, at už to znamená cokoli, velice daleko. Nechme tedy stranou módy světových médií a dělejme si svoje, tzn. pokusme se lépe pochopit tuto fascinující dobu a poskytnout společnosti mapu situace, v níz se nacházíme, i ukazovatele cest do budoucnosti. To snad není pro sociology jen výzva, ale i naše profesionálni povinnost."
V závěru rozhovoru reagoval P. Sztompka na myšlenku, že jako jedna $\mathrm{z}$ inspirací sociologického myšleni dnes v Polsku téměř úplně chybí marxismus, a na otázku, jaké je místo této ideové orientace ve světové sociologii i jaká je prognóza inspirace marxismem a šířeji levicovostí $v$ polské sociologii pro nejbližší léta i pro delší časový horizont.

Sztompka říká, že „Marx dnes v Polsku platí trochu za hříchy, jež nejsou jeho vlastní. Byli to marxisté po Marxovi, leninisté a stalinisté, jakož i cynikové, kteři zdobili autokratickou politiku marxovskou ornamentací, již se stali, použijeme-li marxovské metafory, jeho hrobaři. Avšak nezávisle na politických emocích sociolog nesmí zapominat, že Marx byl vedle Webera a Durkheima jedním z velké trojice tvưrců naši disciplíny. To dnes uznávaji všichni historikové sociologie včetně těch, kteři jsou marxismu nejvzdálenějšíi. Domnívám se, že po čase Marx znovu získá svou normální roli velkého teoretika 19. století, jehož dila je třeba nadále studovat stejně jako díla Comtova, Spencerova a Simmelova, nemluvě o pracích Weberových a Durkheimových. K této tvorbě je nutné se vracet nikoli na kolenou, ale kriticky, hledat v ní spíše badatelskou inspiraci než ideologickou iluminaci nebo politický štít. Americký filozof Alfred North Whitehead kdysi napsal, že věda, jež zapomíná na své předky, je ztracená."

A o levicové orientaci $v$ nejbližších letech Sztompka prohlásil: „Sociální svět ještě dlouho, ne-li na věky, bude plný bídy a hladu, nespravedlnosti a nezaměstnanosti, utrpení a zločinů. Sociolog povahou své profese vidí tyto temné stránky společnosti ostřeji, má pro ně větší cit. A tak jestliže levicovost znamená citlivost pro osudy těch, kteři jsou dole, i péči o jejich zlepšení, bude levicová orientace $\mathrm{v}$ sociologii vždy jednou $\mathrm{z}$ dủležitých výzkumných i teoretických perspektiv.“

Jan Sedláček 